\title{
Neuro-cognition in patients of obstructive sleep apnoea syndrome
}

\author{
Rayees Ahmad Bhat, ${ }^{1}$ Masood Tanvir ${ }^{2}$ Musharaf Bashir ${ }^{1}$
}

${ }^{1}$ Department of Physiology, GMC \& SMHS hospital, Srinagar, Jammu and Kashmir, India

${ }^{2}$ Department of Internal Medicine, GMC \& SMHS hospital, Srinagar, Jammu and Kashmir, India

\section{J Clin Med Kaz 2019;1(51):44-49}

Corresponding Author: Musharaf Bashir, Demonstrator, Department of Physiology, GMC \& SMHS hospital, Srinagar, Jammu and Kashmir, India. Tel.: +917042272380 .

Email: dr.musharaf.mb@gmail.com

\section{Abstract}

Background: Obstructive Sleep Apnoea Hypoapnoea Syndrome (OSAHS) is known to be associated with impairment in neuro-cognitive functions. This impairment in cognition is associated with daytime sleepiness that results in occupational deficits and an increased risk of automobile accidents.

Objectives: The aim of the study was to assess Neuro-cognition in patients of Obstructive Sleep Apnoea Hypoapnoea Syndrome (OSAHS)

Material and methods: Our study was an observational cross-sectional study. Eligible patients $(n=205)$ undergoing polysomnography were categorized into Snoring $(n=105)$, Mild OSA $(n=70)$, Moderate OSA $(n=17)$ and Severe OSA ( $n=13$ ) groups, based on Apnoea Hypoapnoea Index (AHI). The Montreal Cognitive Assessment (MoCA) and the Mini-Mental State Examination (MMSE) Questionnaires were administered to assess their cognitive functions and the correlation between Questionnaire scores and severity of OSAS was determined.

Results: MMSE Questionnaire detected overall cognitive impairment in $22 \%$ of OSA patients while as MoCA Questionnaire detected overall cognitive impairment in $33 \%$ of the same OSA patients. The frequency of mild neurocognitive impairment as detected by MMSE Questionnaire increased progressively as the severity of OSA increased from $\operatorname{Snoring}(6.7 \%)$ to Mild OSA(17.1\%), Moderate OSA(29.4\%) and severe OSA(38.4\%). MoCA Questionnaire demonstrated the same pattern except that it was more sensitive. It detected cognitive impairment of $12.4 \%$ in Snoring group, $27.1 \%$ in Mild OSA group, $41.2 \%$ in Moderate OSA group and 53.9\% in Severe OSA group.

Conclusion: Neurocognitive impairment is common in patients with OSAHS. The MoCA is a more sensitive tool than MMSE for the assessment of mild cognitive impairment in OSAHS patients, whose performance on the MMSE is in the normal range.

Key words: MMSE, MoCA, AHI, OSA, OSAHS

\section{ҰЙҚЫНЫН ОБСТРУКТИВТІ АПНОЭСЫ СИНДРОМЫ БАР ПАЦИЕНТТЕРДЕГІ НЕЙРОКОГНИТИВТІЛІК}

Райис Ахмад Бхат ${ }^{1}$, Масуд Танвир ${ }^{2}$, Мушараф Башир ${ }^{1}$

${ }^{1}$ Физиология бөлімшесі, Шри Махараджа Хари Сингх Мемлекеттік медицина колледжі және Госпиталі, Сринагар, Джамму және Кашмир штаты, Индия ${ }^{2}$ Ішкі медицина бөлімшесі, Шри Махараджа Хари Сингх Мемлекеттік медицина колледжі және Госпиталі, Сринагар, Джамму және Кашмир штаты, Индия

\section{ТҰЖЫРЫМДАМА}

Кіріспе: Бәріміз білетіндей, ұйқының обструктивті апноэ - гипопноэ синдромы нейрокогнитивті функциялардың бұзылуына алып келеді. Мұндай бұзылу күндізгі ұйқышылдықпен байланысты, ол кәсіби шығындарға алып келеді және автокөлік оқиғаларының жоғары қаупін туғызады.

Мақсаттары: Бұл зерттеудің мақсаты ұйқының обструктивті апноэ - гипопноэ синдромына шалдыққан пациенттердің нейрокогнитивтілігін бағалау болып табылады.

Материалдар және әдістері: Біздің шолу көлденең зерттеуімізде өлшемдерге сәйкес келетін және полисомнографиядан өткен (n=205) пациенттер қатысты. Пациенттер мынадай топтарға бөлінді: апноэ-гипопноэ индексіне сәйкес қорылы бар пациенттер (n=105), аз деңгейдегі ұйқының обстуктивті апноэ синдромы бар пациенттер (n=70), орташа деңгейдегі ұйықының обструктивті апноэ синдромы бар пациенттер (n=17) және ауыр деңгейдегі ұйқының обструктивті апноэ синдромы бар пациенттер. Когнитивті фрунцияларды бағалау үшін когнитивті функцияларды бағалаудың Монреаль шкаласы және психикалық мәртебесін бағалаудың Қысқаша шкаласы бойынша сауалнамалар қолданылды, сондай-ақ сауал нәтижелері және ұйқының обструктивті апноэ синдромының ауырлық деңгейі арасында сәйкестіктер айқындалды.

Нәтижелері: Когнитивті функцияларды бағалау үшін психикалық мәртебені бағалаудың Қысқаша шкаласы бойынша сауалнама ұйқының обструктивті апноэ синдромы бар 22\% пациенттерінде жалпы когнитивті бұзылуды айқындады, ал когнитивті функцияларды бағалаудың Монреаль шкаласы бойынша сауалнама ұйқының обструктивті апноэ синдромы бар сол науқастардың 33\%-да бұзылуды байқады. Когнитивті фрункцияларды бағалау үшін психикалық мәртебені бағалаудың Қысқаша шкаласы бойынша сұрау көрсетіп отырғандай, 
орташа нейрокогнитивті бұзылудың жиілігі ұйқының обструктивті апноэ синдромының ауырлығы деңгейінің қорылдан бастап(6.7\%) жеңілге дейін(17.1\%), орташа (29.4\%) және ауыр (38.4\%) күшею шамасына қарай артып отырған. Когнитивті фрункцияларды бағалаудың Монреаль шкаласы бойынша сауал дәл сол көріністі берді, тек ол нақтырақ болды. Сауал ұйқының обструктивті апноэ синдромына шалдыққан қорылы бар пациенттер тобында 12.4\% когнитивті бұзылуды, жеңіл деңгейлі ұйқының обструктивті апноэ синдромына шалдыққан пациенттерде $27.1 \%$ когнитивті бұзылуды, 41.2\% когнитивті бұзылуды орташа деңгейлі ұйқының обструктивті апноэ синдромына шалдыққан пациенттерде және 53.9\% когнитивті бұзылуды ауыр деңгейлі ұйқының обструктивті апноэ синдромына шалдыққан пациенттерде айқындады.

Қорытынды: Нейрокогнитивті бұзылулар ұйқының обструктивті апноэ - гипопноэ синдромы бар пациенттер арасында таралған. Мағыналардың дұрыс диапазонын көрсететін когнитивті функцияларды бағалау үшін психикалық мәртебесін бағалаудың Қысқаша шкаласына қарағанда, когнитивті функцияларды бағалаудың Монреаль шкаласы ұйқының обструктивті апноэ-гипопноэ синдромы бар пациенттер арасында жеңіл когнитивті бұзылуларды бағалаудың нақтырақ құралы болып табылады.

Негізгі сөздер: когнитивті функцияларды бағалау үшін психикалық мәртебесін бағалаудың қысқаша шкаласы, когнитивті функцияларды бағалаудың Монреаль шкаласы, апноэ-гипопноэ индексі, ұйқының обструктивті апноэ синдромы, ұйқының обструктивті апноэ - гипопноэ синдромы

\section{НЕЙРОКОГНИТИВНОСТЬ У ПАЦИЕНТОВ С СИНДРОМОМ ОБСТРУКТИВНОГО АПНОЭ ВО ВРЕМЯ СНА}

Райис Ахмад Бхат ${ }^{1}$, Масуд Танвир ${ }^{2}$, Мушараф Башир ${ }^{1}$

${ }^{1}$ Отделение физиологии, Государственный медицинский колледж и Госпиталь Шри Махараджа Хари Сингх, Сринагар, штат Джамму и Кашмир, Индия

${ }^{2}$ Отделение внутренней медицины, Государственный медицинский колледж и Госпиталь Шри Махараджа Хари Сингх, Сринагар, штат Джамму и Кашмир, Индия

\section{PEЗЮME}

Введение: Как известно, синдром обструктивного апноэ - гипопноэ сна приводит к нарушениям нейрокогнитивных функций. Такое нарушение связано с дневной сонливостью, которая приводит к профессиональным убыткам и повышенному риску автотранспортных происшествий. ноэ сна.

Цели: Целью настоящего исследования является оценка нейрокогнитивности у пациентов с синдромом обструктивного апноэ - гипоп-

Материалы и методы: В нашем обзорном поперечном исследовании приняли участие пациенты, удовлетворяющие критериям и

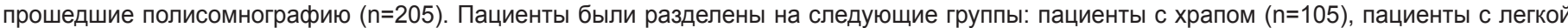
степенью синдрома обструктивного апноэ сна $(\mathrm{n}=70)$, пациенты с умеренной степенью синдрома обструктивного апноэ сна ( $\mathrm{n}=17)$ и пациенты с тяжелой степенью синдрома обструктивного апноэ сна (n=13) согласно индексу апноэ-гипопноэ. Для оценки когнитивных функций были задействованы анкеты по Монреальской шкале оценки когнитивных функций и Краткой шкале оценки психического статуса, а также были определены соответствия между результатами опроса и степенью тяжести синдрома обструктивного апноэ сна.

Результаты: Анкета по Краткой шкале оценки психического статуса для оценки когнитивных функций выявила общее когнитивное нарушение у $22 \%$ пациентов с синдромом обструктивного апноэ сна, в то время как анкета по Монреальской шкале оценки когнитивных функций выявила общее когнитивное нарушение у 33\% тех же пациентов с синдромом обструктивного апноэ сна. Как показал опрос по Краткой шкале оценки психического статуса для оценки когнитивных функций, частота умеренных нейрокогнитивных нарушений увеличивалась по мере усиления степени тяжести синдрома обструктивного апноэ сна от храпа (6.7\%) до легкой (17.1\%), умеренной (29.4\%) и тяжелой (38.4\%) степени синдрома обструктивного апноэ сна. Опрос по Монреальской шкале оценки когнитивных функций показал ту же картину, за исключением того, что она была более точной. Опрос выявил когнитивное нарушение $12.4 \%$ в группе пациентов с храпом, $27.1 \%$ в группе с легкой степенью, $41.2 \%$ в группе с умеренной степенью и 53.9\% в группе с тяжелой степенью тяжести синдрома обструктивного апноэ сна

Заключение: Нейрокогнитивные нарушения распространены среди пациентов с синдромом обструктивного апноэ - гипапноэ сна Монреальская шкала оценки когнитивных функций является более точным инструментом для оценки легких когнитивных нарушений среди пациентов с синдромом обструктивного апноэ - гипапноэ сна, чем Краткая шкала оценки психического статуса для оценки когнитивных функций, которая показывает нормальный диапазон значений.

Ключевые слова: краткая шкала оценки психического статуса для оценки когнитивных функций, Монреальская шкала оценки когнитивных функций, индекс апноэ-гипопноэ, синдром обструктивного апноэ сна, синдром обструктивного апноэ - гипапноэ сна

\section{Introduction}

Obstructive Sleep Apnea Syndrome (OSAS) is a common sleep-related breathing disorder affecting $5 \%$ of the general population [1]. OSAS is characterized by periodic complete or partial cessation of breathing while sleeping. These recurrent events of breathing result in fragmented sleep and recurrent hypoxemia (reductions in hemoglobin oxygen levels) [2]. It has been documented that OSAS causes excessive daytime sleepiness, mood changes and dysfunctions in several cognitive domains $[3,4]$. Obstructive sleep apnea is part of a spectrum of sleep related breathing disorders which also includes central sleep apnea (CSA), mixed sleep apnea, upper airway resistance syndrome (increased respiratory effort without apnea or hypopnea) and snoring [5,6]. Obstructive sleep apnea/hypopnea syndrome is defined as an obstruction of airflow for 10 seconds or longer. It occurs when the muscles relax during sleep, causing soft tissue in the back of the throat to collapse and block the upper airway. Apnea is characterized by the cessation of airflow (decrements in airflow of $\geq 90 \%$ ) for 10 seconds or more $[5,6,7]$. On the other hand, hypopnea is characterized by a reduction of $\geq 50 \%$ in airflow for 10 seconds associated with a $\geq 4 \%$ decrease in oxygen saturation and/or arousal [8] while in accordance with the American Academy of Sleep Medicine guidelines hypopnea is defined as a decrease of $\geq 30 \%$ in airflow followed by $\geq 4 \%$ oxygen desaturation [7]. The diagnosis of the syndrome is based on daytime and nocturnal symptoms and especially on a full-night polysomnogram [9], which includes electroencephalographic, electro-oculographic, electromyographic, oxygen saturation, oral and nasal airflow, respiratory effort, electrocardiographic and leg movement recordings [7]. OSAS severity is defined according to apnea-hypopnea index (AHI), by calculating the sum of apneas plus hypopneas per hour of sleep. According to apnea/hypopnea index (AHI), OSAS patients are divided into 3 groups of severity: mild OSAS (AHI $\geq 5)$, moderate OSAS (AHI= 15-30), and severe OSAS (AHI $\geq 30)$ [7,4]. The occurrence of OSAS among children is $1-3 \%$ [10]. It affects $2 \%$ of women and $4 \%$ of men in middle age adults [1]. In older adults $(\geq 65$ years), it has been reported that $62 \%$ of them present hypopnea episodes and $24 \%$ have apnea episodes above normative index [11]. A newest study on a population - based sample of subjects aged 30 to 70 year found that $19 \%$ of men and $15 \%$ of women have $\mathrm{AHI} \geq 10$ [12].

\section{Materials and methods}

The study was conducted in the Postgraduate Department of Physiology Government Medical College Srinagar. The 
study period was from April 2014 to September 2015. It was a cross-sectional observational study. The study area was Kashmir province of Jammu and Kashmir state. Subjects for the study were selected from the list of patients already dated for Polysomnography at Government Chest Disease Hospital with a primary complaint of snoring, excessive day-time sleepiness and clinical suspicion of OSAS who fulfilled the selection criteria. Government Chest Disease Hospital is an associated Hospital of Government Medical College Srinagar. The group consisted of both males and females of age between 18 years and 65 years. A total of 205 subjects participated in our study. The subjects were selected through simple random sampling. The subjects with the following characteristics were excluded from the study:

- age below 18 years or above 65 years

- patients who refused to participate in the study

- presence of other sleep disorders (International Classification of Sleep Disorders (ICSD-II) diagnosis), such as central sleep apnoea, restless leg syndrome, rapid eye movement (REM)-sleep behavioral disorder, periodic limb movement disorder and narcoleptic spectral disorder, history of receiving medical intervention for sleep-related breathing disorders.

- other diseases such as cancer, severe physical disability and mental disorders, including those requiring concomitant use of medications that would impact on the quality of life, mental health and sleep profiles of the patients.

Subjects were selected only after their proper consent to participate as subjects in the study. History part included name, address, age, sex, contact number, history of illness (both present and past), family history, personal history and drug history. Examination part included the general physical examination and relevant systemic examination. Information regarding quality of sleep, medical history and concomitant use of medications was obtained through patient interviews and reviews of the medical records. Examination part included the general physical examination and relevant systemic examination. The weight of the subjects was measured by a weighing machine, with minimum clothing and shoes removed. The reading was recorded to the nearest kilogram. Body height was measured using a stadiometer. Body mass index (BMI) was calculated by Quetlet's index [weight (kg)/ height (m)2].

The 205 patients were categorized into four groups according to the diagnostic criteria for OSAS, as recommended by the American Academy of Sleep Medicine and based on assessment of AHI by overnight Polysomnography. The four groups were:

I. Primary snoring group (AHI $<5$ events $/ \mathrm{h}, \mathrm{n}=105)$. This group did not meet the polysomnographic (PSG) cut-off criteria for OSAS and patients were categorized into either the 'snoring group' or the 'normal AHI group.

II. Mild OSAS group (AHI $\geq 5$ events/h, $\mathrm{n}=70$ );

III. Moderate OSAS group (AHI $15-30$ events/h, $\mathrm{n}=17$ ); and

IV. Severe OSAS group (AHI $>30$ events/h, $n=13$ ).

All the subjects, at the time of their first visit, underwent neuropsychological testing and overnight polysomnography.

Neuropsychological testing: Two neuropsychological tests, including the MoCA and MMSE were administered to all participants during their first visit, before the clinical diagnosis was established to prevent the bias which could influence the administration and interpretation of the tests.

Montreal Cognitive Assessment: English version of the MoCA questionnaire was used in this study. MoCA is a 30-point test covering eight cognitive domains: (i) visuospatial and executive; (ii) naming; (iii) memory; (iv) attention; (v) language; (vi) abstraction; (vii) delayed recall; and (viii) orientation. Scores $<26$ are considered to be indicative of mild neurocognitive impairment. A bonus point is given to individuals with 12 years or fewer of formal education.

Mini-Mental State Examination: English version of the MMSE questionnaire was administered to assess several areas of cognitive function, including orientation, attention, immediate and short-term recall, language and ability to follow instructions. The maximum score in the MMSE is 30 , with normal values being 25 and above. A score of 21 to 24 is considered as mild cognitive impairment; a score of 10 to 20 is considered as moderate impairment and a score less than 10 is considered as severe cognitive impairment.

Polysomnographic (PSG) studies: For all patients, overnight PSG (Alice ${ }^{\circledR} 5$, Philips Respironics, USA) was performed in an attended setting on the first night of admission at sleep laboratory of Government Chest Disease Hospital, from $10 \mathrm{pm}$ to 6 am the following morning, with at least $7 \mathrm{~h}$ of total recording time considered necessary for successful monitoring. PSG included assessments of airflow using oronasal thermistors and a nasal pressure transducer, thoracic and abdominal respiratory movements, $\mathrm{SaO} 2$ by pulse oximetry, snoring and body position, an electroencephalogram (C3/A2, C4/A1, O1/ A2, O2/A1), electrooculogram, chin and leg electromyogram and ECG. The following PSG variables were measured: AHI (total number of apnoeas and hypopnoeas per hour of sleep), oxygen desaturation index (ODI, defined as the sum of the oxyhaemoglobin desaturations of $>4 \%$ per hour of sleep), minimum pulse oxygen saturation ( $\mathrm{L}-\mathrm{SaO} 2)$, percentage of time spent at $\mathrm{SaO} 2<90 \%$ (Time- $(\mathrm{SaO} 2<90 \%)$ ), non-REM sleep phase 1-3, REM sleep and respiratory arousal index. All PSG data were analyzed by experts, using the new scoring criteria defined by the American Academy of Sleep Medicine in 2007. The traditional

Rechtschaffen and Kales terminology for the five sleep stages (i.e. stages 1, 2, 3, 4 and REM sleep, with stages 3 and 4 collectively referred to as slow wave sleep) was applied in this study. Apnoeas were scored when there was a complete cessation of airflow or $90 \%$ or more drop in the peak thermal sensor excursion for at least $10 \mathrm{sec}$. Hypopnoeas were scored when (i) there was a drop in nasal pressure signal excursion of $30 \%$ or more from baseline lasting at least $10 \mathrm{sec}$, with $4 \%$ or more desaturation from pre-event baseline; (ii) there was a drop in nasal pressure signal excursion of $50 \%$ or more from baseline lasting at least $10 \mathrm{sec}$, with $3 \%$ or more desaturation from preevent baseline; and/or (iii) the event was associated with arousal.

\section{Statistical analysis}

Statistical analysis of the data was carried out by using OpenEpi (Open Source Epidemiological Statistics for Public Health Version 3.03, www.OpenEpi.com). Data variables: Age, Weight, Height, Body Mass Index (BMI), MMSE Scores and MoCA Scores were expressed as Mean \pm SD. Students t-test (unpaired) for difference of means was applied for comparing these parameters among Snoring and OSA groups. Comparisons among the Snoring and OSA groups with respect to cognitive impairment and other nominal data were performed by Chi Square Tests. These tests were two sided and were referred for $\mathrm{p}$-values for their significance. Any $\mathrm{p}$ - value less than $0.05(\mathrm{p}<0.05)$ was taken as statistically significant.

\section{Results}

Out of the total 205 subjects, as shown in Table 1, 100 


\begin{tabular}{|c|c|c|c|c|c|c|c|c|c|}
\hline \multirow[t]{3}{*}{ Subject Group } & \multirow{3}{*}{$\begin{array}{l}\text { Number } \\
\text { of } \\
\text { Subjects }\end{array}$} & \multicolumn{4}{|c|}{ Cognition } & \multicolumn{4}{|c|}{ Percentage } \\
\hline & & \multicolumn{2}{|c|}{ MMSE } & \multicolumn{2}{|l|}{ MoCA } & \multicolumn{2}{|c|}{ MMSE } & \multicolumn{2}{|l|}{ MoCA } \\
\hline & & Normal & Impaired & Normal & Impaired & Normal & Impaired & Normal & Impaired \\
\hline Snoring & 105 & 98 & 07 & 92 & 13 & 93.3 & 6.7 & 87.6 & 12.4 \\
\hline OSA & 100 & 78 & 22 & 67 & 33 & 78 & 22 & 67 & 33 \\
\hline Mild OSA & 70 & 58 & 12 & 51 & 19 & 82.9 & 17.1 & 72.9 & 27.1 \\
\hline Moderate OSA & 17 & 12 & 05 & 10 & 07 & 70.6 & 29.4 & 58.8 & 41.2 \\
\hline Severe OSA & 13 & 08 & 05 & 06 & 07 & 61.6 & 38.4 & 46.1 & 53.9 \\
\hline $\begin{array}{l}\text { All } \\
\text { (OSA+Snoring) }\end{array}$ & 205 & 176 & 29 & 159 & 46 & 85.9 & 14.1 & 77.6 & 22.4 \\
\hline
\end{tabular}

OSA: Obstructive Sleep Apnoea, MMSE: Mini Mental State Examination, MoCA: Montreal Cognitive Assessment

Table 2 Demographic,Polysomnographic and neuro-cognitive parameters of the study subjects

\begin{tabular}{|c|c|c|c|c|c|}
\hline Parameter & Snoring & Mild OSA & Moderate OSA & Severe OSA & $\mathrm{p}$-value \\
\hline Number (n) & 105 & 70 & 17 & 13 & - \\
\hline Gender (Male/Female) & $31 / 74$ & $40 / 30$ & $05 / 12$ & $06 / 07$ & - \\
\hline Age (Mean $\pm S D$ ) years & $49.33 \pm 11.24$ & $50.11 \pm 8.84$ & $57.64 \pm 7.21$ & $51.46 \pm 8.25$ & 0.1179 \\
\hline BMI (Mean \pm SD) kg/m2 & $25.41 \pm 3.80$ & $25.50 \pm 3.45$ & $28.70 \pm 2.86$ & $35.00 \pm 4.08$ & $0.0019^{* *}$ \\
\hline AHI (Mean \pm SD) & $3.47 \pm 1.22$ & $11.05 \pm 3.09$ & $20.25 \pm 2.86$ & $45.42 \pm 10.76$ & - \\
\hline MoCA Score (Mean \pm SD) & $27.33 \pm 1.87$ & $26.50 \pm 1.87$ & $24.52 \pm 2.54$ & $23.07 \pm 5.23$ & $<0.0001^{* * *}$ \\
\hline MoCA $<26$ n (\%) & $13(12.4)$ & $19(27.1)$ & 07 (41.2) & 07 (53.9) & $0.0004^{* *}$ \\
\hline $\begin{array}{l}\text { MMSE Score } \\
(\text { Mean } \pm S D)\end{array}$ & $27.54 \pm 1.99$ & $26.97 \pm 1.94$ & $24.35 \pm 2.69$ & $23.15 \pm 4.92$ & $<0.0001^{* * *}$ \\
\hline MMSE < 25 n (\%) & $07(6.7)$ & $12(17.1)$ & $05(29.4)$ & $05(38.4)$ & $0.0016^{* *}$ \\
\hline
\end{tabular}

OSA: Obstructive Sleep Apnoea, MMSE: Mini Mental State Examination, MoCA: Montreal Cognitive Assessment, BMI: Body mass index, AHI: Apnoea hypopnoea index.

** Highly significant: *** Very highly significant.

(49\%) had OSA (obstructive sleep apnoea) while as 105 (51\%) were classified as snoring group. Out of total 100 OSA patients, $70(70 \%)$ had mild OSA, 17 (17\%) had moderate OSA and 13 (13\%) had severe OSA.

\section{Discussion}

Patients with Obstructive Sleep Apnoea (OSA) often experience daytime sleepiness, and in some cases, also neurocognitive deficits. A large study based on a survey of over 700 individuals with sleep apnoea or snoring showed that men aged 30-60 years with polysomnographically confirmed sleep apnoea were three times more likely to report difficulty in concentrating than individuals whose snoring did not include apnoeic events. 38

The most consistently reported cognitive deficits in OSA, as evaluated by neuropsychological examination using standardized tests, are impairment in attention capacity (e.g. reduced information processing speed and short term memory span), decreased vigilance and executive function deficit (e.g. reductions in mental set shifting, and working memory updating and monitoring, and inhibition of dominant response). It has also been increasingly recognized in recent years that the neurocognitive deficits experienced by OSA patients are largely mild cognitive impairment (MCI), which is an intermediate clinical state between normal cognitive ageing and dementia that precedes and leads to dementia in many cases. MCI is a topic of intense interest because it is considered an appropriate disease state for early therapeutic intervention.

Although several screening instruments are available, there are no consensus criteria for clinical diagnosis of cognitive dysfunction. The MMSE is the most widely used tool, but has been reported to be inadequate for detecting MCI. To address this challenge, the MoCA was developed as a rapid tool with high sensitivity and specificity for assessing patients who present with mild cognitive complaints and usually perform in the normal range on the MMSE. In our study, patients with various severities of OSA, were evaluated using both the MoCA and MMSE questionnaires. Both MMSE and MoCA scores were demonstrated to decrease progressively across the spectrum from snoring, to mild, moderate and severe OSA, but MoCA being more sensitive than MMSE in detecting MCI. In the present study, $33 \%$ of the OSA patients showed cognitive impairment, based on the recommended MoCA cut-off score while as only $22 \%$ of the OSA patients showed cognitive impairment, based on the recommended MMSE cut-off score These findings indicate that MoCA offers better sensitivity for detecting neurocognitive impairment in OSA patients and can be used for neurocognitive assessment of OSA patients with normal MMSE results, who would otherwise be presumed to have no cognitive deficit. The MMSE primarily tests memory and language abilities, whereas the MoCA assesses a broader range of cognitive domains. Based on the findings from this study, MoCA could be used by clinicians as a rapid screening instrument for detecting neurocognitive impairment in patients with OSA.

The cellular and molecular mechanisms underlying the neurocognitive impairment associated with OSA remain poorly defined and warrant further investigation. Multiple pathophysiological processes or pathways, including oxidative stress, inflammatory responses, reduced synaptic plasticity and neuronal apoptosis, have all been suggested to contribute to neuropsychological dysfunction. 
In our study, 205 subjects ( 82 males and 123 females) dated for polysomnography participated. 105 (51\%) had Snoring and 100 (49\%) had Obstructive Sleep Apnoea (OSA) on overnight polysomnography.

Both MMSE and MoCA scores (Mean \pm SD) were significantly lower $(\mathrm{p}<0.000004)$ in OSA group as compared to Snoring group. These results of the study point towards a significant neuro-cognitive impairment in OSA group as compared to Snoring group.

Chen R et al (13) studied 394 patients and classified them into primary snoring group and mild, moderate and severe OSAS groups on the basis of Apnoea Hypoapnoea Index (AHI) and assessed their neuro-cognitive functions by using MoCA and MMSE Questionnaires. Their study demonstrated that $36.4 \%$ of subjects in OSA group and $15.2 \%$ of subjects in Snoring group were having neuro-cognitive impairment on testing by MoCA Questionnaire. On testing with MMSE Questionnaire the study could not detect any cognitive impairment in either group. Our study showed that 33\% of subjects in OSA group and $13 \%$ of subjects in snoring group were having neuro-cognitive impairment on testing by MoCA Questionnaire. The results from the two studies are fairly consistent. In our study, MMSE Questionnaire detected 22\% of subjects in OSA group and 6.7\% subjects in Snoring group having neuro-cognitive impairment. In this case results are different. Their study concluded that MoCA scores decreased progressively across the spectrum from Snoring to severe OSAS. Our study demonstrated the same. Their study showed that MoCA is a more sensitive tool in detecting cognitive impairment in patients of OSA than MMSE. Our Study concurs to that. Their study included subjects aged between 30 and 65 years, while as our study included subjects aged between 18 and 65 years. Their study included association between the degree of hypoxemia and cognitive impairment, while as we did not include this parameter in our study. In their study, subjects in OSA group had significantly higher BMI (Mean \pm SD) than the subjects in the snoring group. Our study demonstrated the same pattern.

Damiani MF et al (14) studied the influence of OSAS on cognitive impairment in 300 patients of OSAS and found that there is a significant impairment of neuro-cognitive functions in patients of OSAS and the severity of impairment increased with the increasing grade of OSAS. The results of our study are consistent with the results of this study.

Bucks RS et al (15) compared the results of the systematic reviews or meta-analysis assessing the effects of OSA on cognition, the relationship between OSA severity and cognition and/or the effects of treatment on cognition in OSA. The Majority of reviews supported deficit in attention/vigilance, delayed longterm visual and verbal memory, Visuospatial/constructional abilities and executive functions in individuals with OSA.
There was also general agreement that language ability and psychomotor functions were unaffected by OSA. Data were equivocal for the effects of OSA on working memory, short-term memory and global cognitive functioning. Attention/vigilance dysfunction appeared to be associated with sleep fragmentation and global cognitive function with hypoxemia. The results are in agreement with the findings of our study except that we did not include hypoxemia and sub-domains of cognition as study parameters in our study.

Borges JG et al (16) made a parallel group design study, which involved 22 patients aged 36-65 years diagnosed with moderate to severe OSAS. Controls were 22 healthy individuals with similar age, gender, intelligence quotient, and schooling to those of the patients. Participants completed a test battery that included measures of 6 distinct executive domains. OSAS subjects and controls were equivalent in all demographic variables and test scores. The Apnea-Hypopnea Index did not significantly correlate with executive performance, but mean oxygen saturation did so with measurements of executive shifting and access to long-term memory. From the study they concluded that OSAS without co-morbidities did not lead to cognitive impairment. The findings are not in agreement with our study.

Gelir E et al (17) used electrophysiological measures to investigate the effects of obstructive sleep apnea on attention, learning, and memory. The mirror-drawing test was used to study procedural memory, and the trail-making test (TMT) was used to evaluate divided attention and executive function. According to the study results, OSA affects attention and executive function adversely. However, they could not detect a significant effect on working or procedural memory. The study results are in agreement with our study results.

\section{Conclusion}

1. Neuro-cognitive impairment was significantly associated with Obstructive Sleep Apnoea Syndrome.

2. Both MMSE and MoCA Questionnaires detected increasing frequency of cognitive impairment with increasing severity of Obstructive Sleep Apnoea.

3. MoCA Questionnaire was more sensitive in detecting cognitive impairment than MMSE questionnaire.

4. High BMI was significantly associated with Obstructive Sleep Apnoea group.

5. Maximum percentage of Snoring and OSA subjects were found in the age range of 51-65 years.

6. MoCA Questionnaire is a cost effective, simple noninvasive method for assessing Neuro-cognitive impairment in Obstructive Sleep Apnoea and it can be used in follow-up of the patients with OSA.

Disclosures: There is no conflict of interest for all authors.

\section{References}

1. Young T, Peppard PE, Gottlieb DJ. Epidemiology of obstructive sleep apnea: a population health perspective. American Journal of Respiratory Critical Care Medicine. 2002; 165(9): 1217 - 39. https://doi.org/10.1164/rccm.2109080

2. American Academy of Sleep Medicine Task Force. Sleep-related breathing disorders in adults: recommendations for syndrome definition and measurement techniques in clinical research. Sleep. 1999; 22(5):667-89. https://doi.org/10.1093/sleep/22.5.667

3. Engleman H, Joffe D. Neuropsychological function in obstructive sleep apnoea. Sleep Medicine. 1999; 3(1):59-78. https://doi. org/10.1016/S1087-0792(99)90014-X

4. TsaraV, Kaimakamis E, Serasli E, Katsarou Z, Christaki P. Health related of life in Greek patients with sleep apnea-hypopnea syndrome treated with continuous positive airway pressure. Sleep Medicine. 2009; 10(2):217-25. https://doi.org/10.1016/j.sleep.2007.12.008

5. Avidan AY. Sleep disordered breathing in the geriatric patient population. Advances in Cell Aging and Gerontology. 2005; 17(1):79112. https://doi.org/10.1016/S1566-3124(04)17004-1 
6. Lim Wet al. Neuropsychological Effects of 2-Week Continuous Positive Airway Pressure Treatment and Supplemental Oxygen in Patients with Obstructive Sleep Apnea: A Randomized Placebo-Controlled Study. Journal of Clinical Sleep Medicine. 2007; 3(4):38086.

7. Qureshi A, Ballard RD. Obstructive sleep apnea. The Journal of Allergy and Clinical Immunology. 2003; 112(4):643-51. https://oi. org/10.1016/j.jaci.2003.08.031

8. Tsai, WH, Flemons WW, Whitelaw WA, Remmersa JE. Comparison of apnea-hypopnea indices derived from different definitions of hypopnea. American Journal of Respiratory and Critical Care Medicine. 1999; 159(1):43-48. https://doi.org/10.1164/ ajrccm.159.1.9709017

9. Andreou G, Galanopoulou G, Gourgoulianis A, Karapetsas A, Molyvas P.Cognitive status in Down syndrome individuals with sleep disordered breathing deficits (SDB). Brain and Cognition. 2002: 50(1):145 -49. https://doi.org/10.1016/S0278-2626(02)00019-2

10. Beebe DW, Gozal D. Obstructive sleep apnea and the prefrontal cortex: towards a comprehensive model linking nocturnal upper airway obstruction to daytime cognitive and behavioral deficits. Journal Sleep Research. 2002; 11(6):1-16. https://doi.org/10.1046/j.13652869.2002.00289.x

11. Ancoli - Israel S et al. Sleep-Disordered Breathing in Community-Dwelling Elderly. Sleep. 1991; 14(6): 486-495. https://doi. org/10.1093/sleep/14.6.486

12. Durán J, Esnaola S, Rubio R, Iztueta A. Obstructive sleep apnea - hypopnea and related clinical features in a population-based sample of subjects aged 30 to 70years. American Journal of Respiratory and Critical Care Medicine. 2001; 163(3):685-89. https://doi. org/10.1164/ajrccm.163.3.2005065

13. Chen R et al. Neurocognitive impairment in Chinese patients with obstructive sleep apnoea hypoapnoea syndrome. Respirology. 2011; 16(5):842-48. https://doi.org/10.1111/j.1440-1843.2011.01979.x

14. Damiani MF, Zito A, Carratù P, Falcone VA, Bega E, Scicchitano P, Ciccone MM, Resta O. Obstructive Sleep Apnea, Hypertension, and Their Additive Effects on Atherosclerosis. Biochem Res Int. 2015; 984193. https://doi.org/10.1155/2015/984193

15. Bucks RS, Olaithe M, Eastwood P. Neurocognitive functions in obstructive sleep apnoea: a meta-review. Respirology. 2013; 18(1):6170. https://doi.org/10.1111/j.1440-1843.2012.02255.x

16. Borges JG et al. Executive functioning in obstructive sleep apnea syndrome patients without comorbidities: focus on the fractionation of executive functions. J Clin Exp Neuropsychol. 2013; 35(10): 1094-107. https://doi.org/10.1080/13803395.2013.858661

17. Gelir E, Başaran C, Bayrak S, Yağcıoğlu S, Budak MT, Fırat H, Ungan P. Electrophysiological assessment of the effects of obstructive sleep apnoea on cognition. PLoS One. 2014; 9(2):90647. https://doi.org/10.1371/journal.pone.0090647

How to cite this article: Rayees Ahmad Bhat, Masood Tanvir, Musharaf Bashir. Neuro-cognition in patients of Obstructive Sleep Apnoea Syndrome. J Clin Med Kaz. 2019; 1(51):44-49 